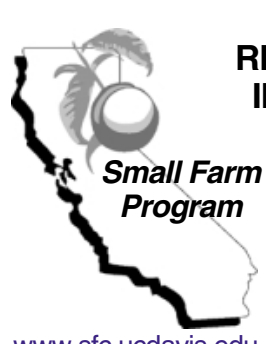

www.sfc.ucdavis.edu

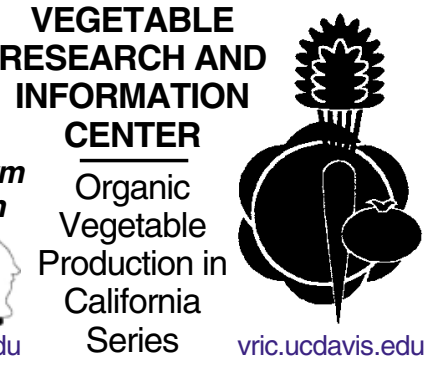

\section{WEED MANAGEMENT FOR ORGANIC CROPS}

RICHARD SMITH, UC Cooperative Extension Farm Advisor, Monterey and Santa Cruz Counties; W. THOMAS LANINI, UCCE Weed Ecologist, UC Davis; MARK GASKELL, UCCE Farm Advisor, Santa Barbara and San Luis Obispo Counties; JEFF MITCHELL, UCCE Vegetable Crops Specialist, Kearney Agricultural Center, Parlier; STEVEN T. KOIKE, UCCE Farm Advisor, Monterey and Santa Cruz Counties; and CALVIN FOUCHE, UCCE Farm Advisor, San Joaquin County

Specific information on organic vegetable production practices in California is scarce, and growers need sound information to guide their management decisions. The Organic Vegetable Production in California Series is made up of publications written by Farm Advisors and Specialists from the University of California's Division of Agriculture and Natural Resources. Each publication addresses a key aspect of organic production practices applicable to all vegetable crops.

Weed management in organic vegetable production systems must involve the use of many techniques and strategies, all with the goal of achieving economically acceptable weed control and crop yields. Weeds can always be pulled or cut, but the question is simply how much time and money can a grower expend to reduce weed pressure. The more a grower is able to reduce weed pressure, the more economical it is to produce crops.

Ideally, growers would like to achieve a level of zero weeds on the farm. In practice, this may not be achievable, but any reduction in weeds and in the amount of weed seed or perennial propagules reaching the soil will make subsequent weed control operations less expensive. An understanding of what resources weeds require and why weeds are present in the first place is useful when you begin to formulate a control strategy.

For weeds to grow, they must have access to water, nutrients, and light. The first or biggest plant to occupy a site has a competitive advantage over later plants. The cultural practices used in vegetable production (for instance, using transplants, pre-emergent flaming of weeds, pre-germination of weeds) often provide opportunities for the crop to gain that advantage. The goal is for the crop to outcompete the weeds, reducing the availability of resources to the weeds. If you can give the crop a competitive advantage through organically acceptable techniques, subsequent hand weeding operations and costs can be minimized. The following are common techniques available to organic growers to manage weeds in vegetable production operations.

\section{CULTURAL PRACTICES}

\section{Water Management}

Effective water management is key to controlling weeds in a vegetable operation. There are a number of ways that careful irrigation management can help you reduce weed pressure on your crops:

- Pre-germination of weeds. In pre-germination, irrigation or rainfall germinates weed seeds just before the cash crop is planted. The newly germinated weeds can be killed by light cultivation or flaming. Pre-germination should occur as close as possible to the date of planting to ensure that changes in weather conditions do not have an opportunity to change the spectrum of weeds (cool vs. warm season) in the field.

- Planting to moisture. Another technique similar to pregermination is planting to moisture. After weeds are killed by cultivation, the top 2 to 3 inches of soil are allowed to dry and form a dust mulch. At planting, the dust mulch is pushed away and large-seeded vegetables such as corn or beans can be planted into the zone of soil moisture. These seeds can germinate, grow, and provide partial shading of the soil surface without supplemental irrigations that would otherwise provide for an early flush of weeds.

- Buried drip irrigation. Drip tape buried below the surface of the planting bed can provide moisture to the crop and minimize the amount of moisture that is available to weeds closer to the surface. If properly managed, this technique can provide significant weed control during periods without rain.

\section{Crop Competition}

Crops that grow vigorously can often outcompete weeds. Weeds grow best where competition is sparse; for instance, between rows or in gaps in a crop stand. Crops that are well adapted to their planted areas are often better competitors since they will tend to occupy a site rapidly. If you increase the density of the crop by decreasing the in-row spacing or by reducing the space 
between rows you will improve the crop's competitiveness. A close-planted crop will close the canopy more rapidly, reducing the weeds' ability to compete. Some crops (including tomato, bean, and sweet corn) compete effectively with weeds if given an early competitive advantage, while others (including onion and garlic) never establish a competitive canopy. The use of transplants give the crop an advantage over the weeds because transplants enter the field larger and more developed that the weeds. With help from subsequent cultivation or hand weeding operations, a transplanted crop can develop a full canopy and crowd out weeds.

\section{Reducing the Weed Seed Bank}

Practices that reduce the production of weed seed also reduce weed pressure and can help keep weeding costs down over time. In an ideal situation, no weed would be allowed to go to seed. Any that do go to seed can aggravate weed problems for many years to come. As an example, common purslane seed has been shown to remain viable for over 20 years in the soil, and black mustard seed survives for over 40 years. The longevity of weed seed, together with the large numbers of seed produced by individual plants $(100,000$ per plant for large purslane or barnyardgrass plants), can lead to the long-term build-up of enormous seed banks in the soil. If you make it a policy to remove weeds prior to seed production, you can reduce weed pressure in subsequent seasons.

Careful weed management during the season is important, but it must be followed up with off-season weed control as well. Short-season crops such as lettuce can provide opportunities for frequent cultivations and a rapid turnover of crops on the land, thus reducing some weeds' ability to mature and set seed. Highly competitive cover crops can also smother weeds. If you carry weeds with seed out of the field for disposal, you can also significantly reduce the seed bank. Each of these techniques can help growers minimize weed problems, and that translates to lower hoeing bills.

\section{CULTIVATION}

Cultivation is probably the most widely used weed control method in organic vegetable operations. Mechanical cultivation uproots or buries weeds. Burial works best on small weeds, while larger weeds are better controlled by destruction of the root-shoot connection or by slicing, cutting, or turning the soil to eliminate the root system's contact with the soil. Cultivation is effective against almost all weeds, with the exception of certain parasitic forms such as dodder. Effective cultivation must precisely and accurately target weed- growth areas, and so requires good land preparation and bed shaping. Shallow cultivation usually is best, since it brings fewer weed seeds to the surface. Level beds allow more precise depth of tillage. Cultivation requires relatively dry soil; subsequent irrigations should be delayed long enough to prevent the weeds from re-rooting. In addition, cultivations should be carried out early enough in the growth cycle to kill weeds such as burning nettle and purslane that set seed early in the growth cycle.

The goal of cultivation is to cut out weeds as close to the seed row as possible without disturbing the crop. In most cases, precision cultivation can take care of the weeds on over 80 percent of the bed. The remaining weeds must be removed from the seed row by hand or using other mechanical means. Here are some common cultivation implements:

- Various knives, L-shaped and crescent-shaped beet hoes, and sweeps can be used to cut and uproot weeds on bed tops within 1 to 3 inches of the crop row. These can sometimes be combined with reversed-disc hillers that cut vining weeds such as field bindweed and move soil away from the crop row. Disc hillers are often reversed as crops get larger so they will throw soil around the base of the crop plant to bury weeds. Rolling cultivators (Lillistons) have become common cultivating implements for a number of crops. A rolling cultivator's primary purpose is to uproot weeds, but it can also be adjusted to throw soil and bury weeds in the crop row.

- A new generation of cultivators has been developed to remove weeds from between the seed rows, and in some situations from the seed row itself. Spring-tine cultivators, torsion Bezzerides cultivators, Budding in-row weeders, and brush hoes all can be adjusted to take out weeds between seed rows or close to the seed row. Some of these cultivators can remove weeds from the seed row itself in fields planted to tough-stemmed crops like cotton. Computer-guided cultivators that can distinguish the crop from weeds are under development and may soon be able to remove weeds selectively from within the seed row.

- Cultivation implements are often mounted on sleds for accurate, close cultivation in row crops. Guide wheels, cone wheels, and other devices are also used, but in general these are less precise than sleds. Various implements can be attached to these guidance setups to remove weeds.

Even the best cultivators will not eliminate all weeds, so some hand weeding is often necessary. It is easier to remove weeds by hand while they are small. The proper timing of cultivations depends on the speed of weed growth: in spring a two- to three-week period 
is about right; in the fall or winter, longer periods between cultivations may be appropriate. The practice and experience of the grower are important factors in effective cultivation.

Weeds that compete with the crop early in the crop cycle may be more damaging to crop yield than weeds that establish later in the season. Late-season weeding may disturb the crop's root system or knock off flowers or fruit, which may reduce yields. Obviously, late season cultivations to reduce weed seed production must be weighed against the potential for yield loss.

\section{FLAMERS}

Flamers are useful for weed control. Propane-fueled models are the most common. Flaming does not burn weeds to ashes; rather, the flame rapidly raises the temperature of the weeds to more than $130^{\circ} \mathrm{F}$; The sudden increase in temperature causes the plants' cell sap to expand, rupturing the cell walls. For greatest flaming efficiency, weeds must have fewer than two true leaves. Grasses are difficult to impossible to kill by flaming because the growing point is protected underground. After flaming, weeds that have been killed rapidly change from a glossy appearance to a duller appearance.

Flaming can be used prior to crop emergence in slow-germinating vegetables such as peppers, carrots, onions, and parsley. In addition, flaming can be used postemergence on crops such as young onion and garlic or as a directed treatment to the base of tougher crops (such as sweet corn) when they are 12 or more inches tall. Postemergence flaming does adversely impact the yield of the crop, so its use must be weighed against the potential damage the weeds might cause. Typically, flaming can be applied at a speed of 3 to 5 mph through fields, although this depends on the heat output of the unit being used. Best results are obtained under windless conditions, as winds can prevent the heat from reaching the target weeds. The efficiency of flaming is greatly reduced if moisture from dew or rain is present on the plants. Early morning and early evening are the best times to observe the flame patterns and adjust the equipment.

\section{STERILIZATION}

Soil sterilization in organic agriculture involves the use of heat or naturally generated biocides to kill weeds. Heat is applied as steam or by soil solarization. In steam sterilization, the steam is injected into the soil to kill weed seeds. The large quantities of fuel and water required by this technique make it an expensive choice, so its use is limited to small acreages of high-value hor- ticultural crops or landscaping. Ozone is a naturally occurring biocide that is being researched for use as a soil sterilant. The ozone is generated mechanically and then injected into the soil. Ozone injection shows promise as a weed-reduction tool, but it is unclear at this time whether this technique will be considered an organically acceptable practice.

Soil solarization involves placing a clear plastic mulch over a tilled, moist soil to allow the solar energy to heat the soil and kill germinating weed seeds. To be most effective, solarization should be performed during summer and fall periods of maximum solar radiation exposure. These are the steps involved in solarization:

1. Prepare the area as if for planting, making certain that the area is as level as possible.

2. Irrigate to field capacity and then place the clear plastic mulch over the area, covering the edges of the plastic with soil to hold them in place. Irrigation and pressing the plastic down for a tight fit against the soil reduces the amount of airspace and ensures good transfer of heat. Any tears in the plastic should be promptly repaired or they will allow heat to escape.

3. Allow the plastic to remain in place for a minimum of 4 weeks (length of treatment depends on the amount of solar radiation).

4. Remove the plastic mulch and immediately plant the crop. You can remove the plastic or use it as a plastic mulch for the subsequent crop by burning holes in the film and transplanting into those holes. Solarization generally yields successful results in the Central and Imperial Valleys, but is less reliable in coastal valleys.

\section{MULCHES}

Mulching is another weed control method. A mulch blocks light, preventing weed germination and growth. The materials that can be used as mulches are varied, and include plastics and organic materials such as municipal yard waste, wood chips, straw, hay, sawdust, and newspaper. To be effective, a mulch needs to block all light to the weeds, and some mulch materials require a thicker application layer that others to accomplish this.

Plastic mulches vary in thickness from 1.5 mil to about 4 mils. The most common color for weed-control plastic is black, since it completely blocks light. More recently, a clear, infrared-transmitting (IRT) plastic has been introduced. The IRT plastic blocks certain wavelengths of light but allows others to pass, and that heats the soil better for early-season crop growth. Plastic mulches are generally placed on the beds and their edges covered with dirt to keep them from blowing 
away. Drip irrigation is needed to get moisture to the crop under the plastic mulch. Certain weeds, including nutsedge, are able to penetrate the plastic and so are not completely controlled by plastic mulches. Other weeds can grow in the openings provided for crops. Further problems with plastic mulches include difficulties keeping them in place under windy conditions, disposal after the crop is harvested (they are not as yet recyclable), and their cost (including the cost of needed drip irrigation).

Organic mulches such as municipal yard waste, straw, hay, and wood chips must be maintained in a layer 4 or more inches thick in order to block out light. Organic mulches break down over time, and the original thickness typically reduces by 60 percent after one year. Coarse green waste works better as a mulch. Organic mulches are mostly used for permanent crops, landscaping, and noncrop areas, although they are also very effective for transplanted vegetables.

Organic mulches can be grown in place. Plants used to produce organic mulches include cereals, clovers, vetches, and fava beans. These mulches (or living mulches, as they are sometimes termed) must die or be killed before or shortly after crop planting in order to avoid excessive competition with the crop. Living mulches were developed in the eastern United States, but are currently being tested on various fruiting vegetables in California (see UC ANR Publication 7248, Soil Management and Soil Quality for Organic Crops).

\section{BENEFICIAL ORGANISMS}

Weeds are subject to disease and insect attacks just as crops are. Most biological control of weeds occurs in range or noncrop areas. As a result, biological control has little relevance for vegetable growers.

Geese have been used for weed control in tree, vine, and certain row crops. Most types of geese will graze weeds, but Chinese weeder geese are considered the best for row crops. Chinese weeder geese are smaller than other types and tend to walk around delicate crop plants rather than over them. Geese prefer grass species and will eat other weeds and crops only if they are hungry and all of the grasses are gone. If confined, geese will even dig up and eat Johnsongrass and bermudagrass rhizomes. You must take care to avoid placing geese near any grass crops such as corn, sorghum, or small grains, as this is their preferred food. Fruiting vegetables, such as tomatoes when they begin to color, might also be vulnerable, so geese would have to be removed from tomato fields at certain times. Geese require drinking water, shade during hot weather, and protection from dogs and other predators.

\section{CHEMICAL CONTROL}

Herbicides are chemicals that kill or suppress plants by affecting their physiological processes. Only a limited number of herbicides are organically acceptable, and these include contact materials such as acetic acid (vinegar), citric acid, and solutions of sodium nitrate, as well as a preemergent material, corn gluten. Herbicides can be used for selective weed control by manipulating the timing of application or placement of material, or by exploiting differences in the chemical tolerances of the crop and the target weed. Weeds that emerge before the crop can be killed with contact herbicides (acetic acid, etc.). These herbicides kill plants that have emerged, but have no residual activity on those that emerge later. Corn gluten is a preemergence material that is applied to the soil to suppress weeds as they germinate. Currently, the efficacy of these organically acceptable herbicides is marginal at best.

\section{OTHER PUBLICATIONS IN THIS SERIES}

Organic Certification, Farm Production Planning, and Marketing, UC ANR Publication 7247

Soil Management and Soil Quality for Organic Crops, UC ANR Publication 7248

Soil Fertility Management for Organic Crops, UC ANR Publication 7249

Insect Pest Management for Organic Crops, UC ANR Publication 7251

Plant Disease Management for Organic Crops, UC ANR Publication 7252 
Weed Management for Organic Crops • 5

\section{RESOURCES}

\section{Books}

Bowman, G. (ed.) 1997. Steel in the fields: A farmer's guide to weed management tools. Beltsville, MD: Sustainable Agriculture Network.

Crampton, B. 1974. Grass in California. Berkeley: University of California Press.

Whitson, T. D. (ed.) 1992. Weeds of the West. Newark, CA: Western Society of Weed Science.

\section{Videos}

Bellinder, R., and J. Colquhoun. 1998. New Tools for Mechanical Weed Control in Vegetables. Ithaca, NY: Cornell University.

Grubinger, V., and M. J. Else. 1997. Vegetable Farmers and Their Weed-control Machines. Burlington, VT: University of Vermont and University of Massachusetts Extension.

Lanini, T. 1993. Cultural Weed Control in Vegetables. Davis, CA: University of California Division of Agriculture and Natural Resources, Program V93-E.

\section{Websites}

California Weed Science Society: http:/ /www.cwss.org/

University of California Integrated Pest Management Program: An excellent source of information on weed control in specific crops: http:/ /www.ipm.ucdavis.edu/

Weed Science Program at UC Davis: an excellent source of photographs and biological information on California weeds, with many links to other sites: http://veghome.ucdavis.edu/weedsci/www/ welcome.html

Western Weed Science Society: http://www.wsweedscience.org/

\section{Equipment}

Contact local farm equipment dealers and distributors of cultivation equipment. In addition, consult the annual American Vegetable Grower Magazine Buyers' Guide.

An electronic version of this publication is available on the University of California ANR Communication Services website at http:/ / anrcatalog.ucdavis.edu.

Publication 7250

(C) 2000 by the Regents of the University of California,

Division of Agriculture and Natural Resources. All rights reserved.

To simplify information, trade names of products have been used. No endorsement of named products is intended, nor is criticism implied of similar products that are not mentioned.

The University of California prohibits discrimination against or harassment of any person employed by or seeking employment with the University on the basis of race, color, national origin, religion, sex, physical or mental disability, medical condition (cancer-related or genetic characteristics), ancestry, marital status, age, sexual orientation, citizenship, or status as a covered veteran (special disabled veteran, Vietnam-era veteran or any other veteran who served on active duty during a war or in a campaign or expedition for which a campaign badge has been authorized).

University Policy is intended to be consistent with the provisions of applicable State and Federal laws.

Inquiries regarding the University's nondiscrimination policies may be directed to the Affirmative Action/Staff Personnel Services Director, University of California, Agriculture and Natural Resources, 1111 Franklin, 6th Floor, Oakland, CA 94607-5200 (510) 987-0096. 